Instytut Archeologii i Etnologii PAN

$w$ Warszawie

Paweł Wójcicki

\title{
ZESPOŁY KULTUROWE NA OBSZARZE ŻELAZNEJ BRAMY U SCHYŁKU PÓŹNEGO GLACJAŁU I NA POCZĄTKU HOLOCENU
}

Zarys treści. Artykuł dotyczy zasadności klasyfikacji zespołów kulturowych w Żelaznej Bramie, jako przykładów osadnictwa mezolitycznego. Na badanym obszarze dla późnego glacjału i wczesnego holocenu wyróżniamy trzy zespoły kulturowe: protoclisurien, clisurien i tzw. kulturę Schela Cladovei-Lepenski Vir. Ugrupowania te w różnym stopniu kontynuowały tradycję leśnego modelu adaptacyjnego kultury górnopaleolitycznej, zatem, należy łączyć je z epipaleolitem.

Słowa kluczowe: późny glacjał, epipaleolit, clisurien.

\section{OPIS REGIONU I HISTORIA BADAŃ}

Obszar Żelaznej Bramy rozpościera się na 134-kilometrowym odcinku Dunaju (230 km wraz ze strefą dolinną), pomiędzy miejscowościami Baziaş i Gura Văii (ryc. 1). Chcąc uchwycić całość zjawisk zachodzących w opisywanym regionie u schyłku późnego glacjału i na początku holocenu, archeolodzy niejako sztucznie poszerzyli granicę obszaru w kierunku wschodnim, obejmując również stanowiska archeologiczne położone w strefie dolinnej (Bonsall 2008). Należy wspomnieć, że przed rozpoczęciem badań archeologicznych w rejonie Żelaznej Bramy, terminem tym określano jedynie trzykilometrowy, stosunkowo wąski odcinek rzeki o szybkim, utrudniającym żeglugę nurcie, pomiędzy miejscowościami Vârciorova a Gura Văii (Boroneanţ A. 2012). Dziś terminem Żelaznej Bramy można określić cały obszar na granicy Rumunii i Serbii, ograniczony od wschodu doliną rzeki Nera (w miejscowości Baziaş), a od zachodu tamą Żelazna Brama II (Bonsall 2008).

Region tworzą trzy zróżnicowane morfologicznie strefy: Wąwóz Żelaznej Bramy, Karpaty wraz z górami Wschodnioserbskimi oraz dolina Dunaju. Malowniczy krajobraz licznych wąwozów i dolin niewielkich rzek, uformo- 


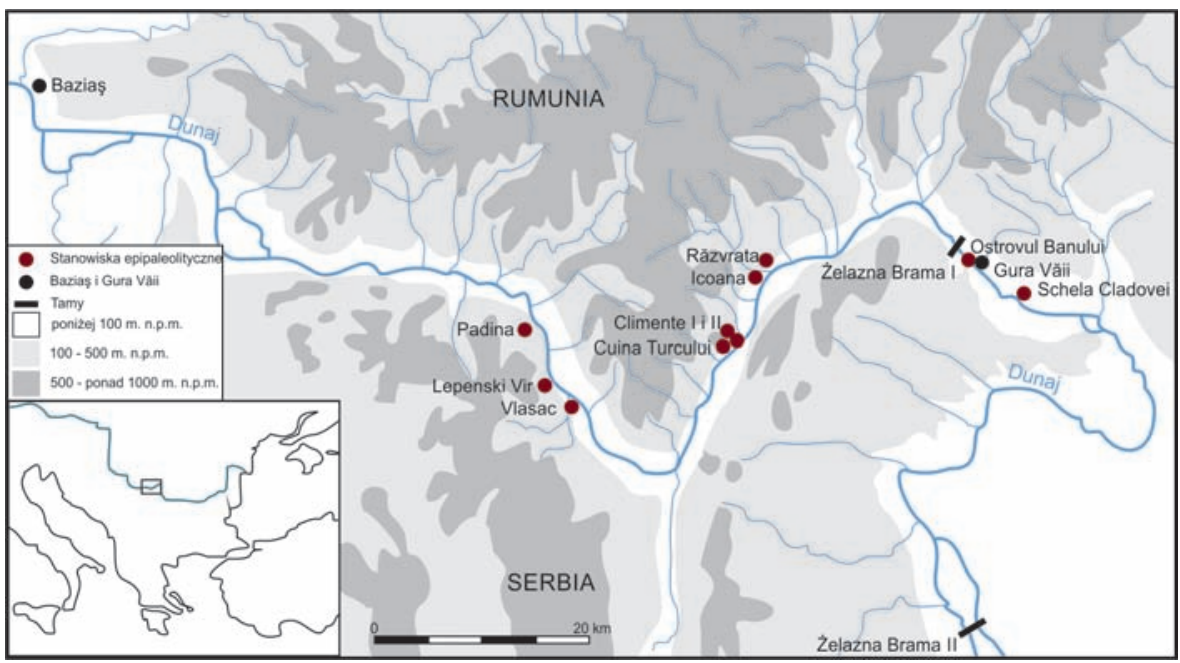

Ryc. 1. Stanowiska epipaleolityczne w regionie Żelaznej Bramy (wg Bonsall 2008; rys. P. Wójcicki)

Fig. 1. Epipaleolithical sites in Iron Gates region (after Bonsall 2008; drawn by P. Wójcicki)

wanych w skałach wapiennych charakteryzujących się występowaniem wielu jaskiń i schronisk skalnych, kontrastuje ze strefą o równinnej rzeźbie terenu. Zróżnicowanie krajobrazu nadawało znaczny potencjał ekonomiczny i było powodem częstego osiedlania się grup łowców-zbieraczy w tym regionie.

Występowanie stanowisk z późnego glacjału i początków holocenu w Żelaznej Bramie zostało stwierdzone w 1961 roku. Wówczas grupa archeologów prowadzona przez Constantina S. Nicolăescu-Plopșora odsłoniła epipaleolityczne warstwy w jaskini Climente II i schronisku skalnym Cuina Turcului. Nowe zespoły kulturowe zostały nazwane Clisurienem, choć nie wszyscy archeolodzy byli zgodni w kwestii nazewnictwa. Florea Mogoşanu zaproponowała nazwę Romanellian, nawiązując do odkryć w Grotta Romanelli we włoskiej Apulii. Natomiast Alexandru Păunescu, w kontekście tych odkryć używał nazwy Romanello-Azillian (Boroneanţ, Dinu 2006).

Od 1964 roku w regionie Żelaznej Bramy prowadzono systematyczne prace wykopaliskowe. Było to konsekwencją decyzji rządów rumuńskiego i jugosłowiańskiego o rozpoczęciu budowy dwóch tam na Dunaju, pełniących funkcję hydroelektrowni oraz ułatwiających nawigację po rzece. Wówczas podjęto ratownicze badania archeologiczne, które zaowocowały rozpoznaniem ponad 30 stanowisk epipaleolitycznych, protoneolitycznych i neolitycznych. W wyniku rozpoczęcia w tym rejonie działalności dwóch tam - Porțile de Fier I (w 1971 roku) i Porțile de Fier II (w 1984 roku), niemal wszystkie 
stanowiska archeologiczne znalazły się pod wodą. Obecnie, jedynym wciąż badanym stanowiskiem na rumuńskim brzegu Dunaju jest Schela Cladovei; inne dostępne, lecz niebadane stanowisko to jaskinia Climente II (Bonsall 2008).

\section{PROBLEM KLASYFIKACJI ZESPOLÓW KULTUROWYCH W ŻELAZNEJ BRAMIE}

Wśród archeologów prowadzących badania w regionie Żelaznej Bramy zauważalne są znaczne różnice $\mathrm{w}$ interpretowaniu odkrytych tam zespołów kulturowych, dotyczące klasyfikacji poszczególnych stanowisk oraz przynależności badanych zespołów do ugrupowań mezolitycznych bądź epipaleolitycznych. Zapewne wynikają one z początkowego braku komunikacji między rumuńskimi a jugosłowiańskimi badaczami, którzy dopiero po opublikowaniu wstępnych wyników badań i nawiązaniu personalnych kontaktów rozpoczęli realny dialog i współpracę (Boroneanţ V. 2000).

Jak wspomniano, niektórzy archeolodzy rumuńscy zwracali uwagę na podobieństwo odkryć naddunajskich do tych, które określano jako epigrawetien śródziemnomorski (Boroneanţ V. 2000, s. 38). Jednak używanie nazwy Romanellian stoi w sprzeczności ze słuszną - zdaniem autora - opinią Margharity Mussi, która widzi ów zespół jako regionalną grupę charakterystyczną jedynie dla Apulii (Mussi 2002, s. 334). Istnieje szereg zespołów o podobnym inwentarzu, na który składały się zazwyczaj drapacze tarnowiańskie, duże i małe formy tylcowe, różnorodne zbrojniki, w tym również geometryczne oraz szereg innych narzędzi charakterystycznych niekiedy tylko dla niewielkiego obszaru. Owe zespoły zbiorczo nazywane epigrawetienem bądź epitardigrawetienem (Kozłowski J. K. 1973; Ginter, Kozłowski 1990), a także epigrawetienem śródziemnomorskim i epigrawetienem śródziemnomorskim i naddunajskim (Kozłowski J. K. 2004), mają szereg regionalnych odmian, do których zaliczamy również zespoły w regionie Żelaznej Bramy. Nawiązywanie do nazewnictwa $\mathrm{z}$ różnych części kontynentu europejskiego i poszerzanie zasięgu danych zjawisk kulturowych lub wyznaczanie kolejnych, niekiedy odległych enklaw tych zespołów bez solidnych podstaw taksonomicznych, nie może wiarygodnie argumentować obecności rozległych dyfuzji kulturowych. Przykładem pochodzącym z Niżu Europejskiego jest występowanie grotów Lyngby, które - jako skuteczna broń myśliwska - służyły wielu, różnym kulturowo, grupom łowców-zbieraczy. Z tego względu nie mogą być one wyznacznikiem kulturowym (Kobusiewicz 2009). Dla regionu Żelaznej 
Bramy takim narzędziem może być ostrze typu romanelskiego ${ }^{1}$ lub ostrze typu Climente $\mathrm{I}^{2}$, a także współwystępowanie różnych form drapaczy tarnowiańskich oraz dużych i małych form tylcowych.

Aby dobrze zrozumieć problem nazewnictwa zespołów kulturowych w regionie Żelaznej Bramy, niezbędne jest przywołanie szerszego kontekstu późnoglacjalnych i wczesnoholoceńskich znalezisk z Rumunii. Pierwsze informacje o materiałach uznawanych za mezolityczne ukazały się w 1928 roku, za sprawą węgierskiego archeologa Mártona Roska; swoje odkrycia w Siedmiogrodzie zaliczył on do Campignanu. Z tym samym zespołem kulturowym Nicolae N. Moroşan utożsamiał swoje znaleziska z Besarabii, pozyskane w 1929 roku (Boroneanţ, Dinu 2006). Najważniejsza z wczesnych opinii w rumuńskiej archeologii należy do Constantina S. Nicolăescu-Plopșora, który na fali odkryć z końca lat 20. XX wieku opublikował szereg znalezisk z obszaru Oltenii nawiązujących do zespołów świderskich; wśród nich wyróżnił dwa zespoły kulturowe: Cleanovian i Plopşorană (Nicolăescu-Plopşora 1931). Nieco później zespoły te zostały połączone w jeden kompleks Plopşor-Cleanov, mający charakteryzować się przemysłem krzemiennym typowym dla Tardenoisianu z jednoczesnymi silnymi wpływami świderskimi (Berciu 1939; Boroneant, Dinu 2006). Mające być jak „un rayon de lumière sur le chaos nébuleux du mésolithique" ustalenia ówczesnych badaczy (Nicolăescu-Plopșor 1931, s. 347) okazały się węzłem gordyjskim dla przyszłych pokoleń archeologów.

\section{ZESPOEY KULTUROWE. CHRONOLOGIA I PRÓBA KLASYFIKACJI}

Posługując się stworzonym przez Vasile Boroneanţ podziałem ugrupowań w Żelaznej Bramie, a także nawiązując do chronologii owych zjawisk, szeroko dyskutowanej w literaturze (Srejović 1969; Voytek, Tringham 1989; Boroneanţ V. 2000; Ciârciumaru i in. 2007; Bonsall 2008; Borić, French, Dimitrijević 2008; Rusu 2011; Boroneanţ A. 2012) można wyróżnić trzy zespoły kulturowe z późnego glacjału i początków holocenu w regionie Żelaznej

\footnotetext{
${ }^{1}$ Narzędzia z krawędzią równoległą lub ukośną do osi, uformowaną stromym retuszem tylcowym, nazywane również ostrzami clisuriańskimi (Boroneanţ V. 2000) lub azylskimi (Păunescu 2001). Vasile Boroneanţ (2000) uważa, że mają one swoje odpowiedniki we wcześniejszych ostrzach graweckich i chatelperrońskich.

2 Narzędzia $\mathrm{z}$ drobnym, stromym retuszem przykrawędnym, łuskane prawie na całym obwodzie; nazywane są również fléchettes (Boroneanţ V. 2000).
} 
Bramy: protoclisurien, clisurien i pierwsza faza tzw. kultury Schela Cladovei-Lepenski Vir.

Po analizie proponowanych chronologii epipaleolitu w Żelaznej Bramie widoczne są niekonsekwencje przejawiające się naprzemiennym stosowaniem kalendarzowego i konwencjonalnego określenia czasu przez jednego autora (Rusu 2011). Najpoważniejszy problem stanowi jednak niewielka liczba dat radiowęglowych dla stanowisk we wspomnianym regionie. Powołując się na wspomniane publikacje i w nawiązaniu do propozycji Adana Walanusa i Doroty Nalepki (2010) w kwestii kalibrowania chronozon późnego glacjału i holocenu, chronologia epipaleolitu w Żelaznej Bramie przedstawia się następująco:

- Protoclisurien (około 13000/12000 cal BC) stwierdzony został tylko w jaskini Climente I. Dla tego stanowiska nie dysponujemy pomiarami wie$\mathrm{ku}$ metodą radiowęglową. Chronologia została ustalona na podstawie analiz stratygraficznych i technologiczno-typologicznych (Păunescu 2000).

- Clisurien (około 13000/12000-9500 cal BC), którego początkowe, niepewne określenie wieku wynika z dużego, niemal tysiącletniego zakresu błędu w pomiarach radiowęglowych warstwy I ze schroniska skalnego Cuina Turcului. Istotne jest, że dla próbki pobranej z niższego poziomu tej samej warstwy uzyskano przedział czasu 12232-11711 cal BC. Adina Boroneanţ (2000) uważa natomiast, że zespoły z jaskini Climente II są starsze niż te z Cuina Turcului. Nazywa je odpowiednio pierwszą i drugą fazą clisurienu. Mając jednak na uwadze ostrożności i rzetelności teoretycznych metod badawczych początek zjawisk związanych z clisurienem powinno przesunąć się na około 12000 cal BC.

- I faza tzw. kultury Schela Cladovei-Lepenski Vir (9500-7200 cal BC) budzi najmniej wątpliwości, gdyż jest potwierdzona wieloma datowaniami radiowęglowymi (Rusu 2011).

Protoclisurien w Żelaznej Bramie został rozpoznany w latach 1965 i 1968-1969, w trakcie badań jaskini Climente I (zwanej również Gura Ponicovei), w miejscowości Dubova. Natrafiono tam na znaleziska mustierskie, oryniackie, epigraweckie oraz osadnictwo neolityczne i młodsze (Păunescu 2000, s. 361-362). W epigraweckim poziomie osadniczym odnaleziono między innymi łuszcznie, smukłe drapacze o surowych bokach, ostrza typu Climente I, mikrograwety, ostrza graweckie, ostrza azylskie, retuszowane wióry, tylczaki pełnołukowe oraz wiórki Dufour i fragmenty jednozadziorców; w inwentarzu odnotowano znaczy udział wiórów (Boroneanţ V. 1999; 2000, s. 29-30). W publikacjach V. Boroneanţ oraz Alexandru Păunescu istnieją niewielkie różnice w kwestii przyporządkowania niektórych wyrobów do 
poszczególnych ugrupowań kulturowych. Dwa wióry z retuszem zębatym V. Boroneanţ zaliczył do protoclisurienu, natomiast A. Păunescu jeden do musterienu, drugi zaś do oryniaku. W inwentarzu brakuje charakterystycznych dla epipaleolitu różnych form drapaczy tarnowiańskich. Wątpliwości budzi również analiza archeozoologiczna stanowiska w jaskini Climente I. We wszystkich warstwach mechanicznych, przebadanych pod kątem obecności poszczególnych gatunków zwierząt, występowały kości niedźwiedzia jaskiniowego. Współwystępowanie kłów Ursus spelaeus i - nazywanych różnie przez autorów rumuńskich - ostrzy typu Climente I (fléchettes) sugeruje bądź znacznie starsze konotacje archeologiczne niż to początkowo przypuszczano, bądź - co jest bardziej prawdopodobne - intensywne procesy podepozycyjne, niezwykle charakterystyczne dla stanowisk jaskiniowych (Krajcarz 2009). Owe procesy wpływające na redepozycję kości i wyrobów krzemiennych, niewątpliwie zaburzają obraz pradziejowego osadnictwa w jaskini Climente I.

Kolejnym zespołem kulturowym w Żelaznej Bramie jest clisurien³ ${ }^{3}$ uznawany za lokalną odmianę romanellianu, nawiązujący również do valourgienu i azillianu. Clive Bonsall zalicza ten okres do wczesnego mezolitu (Bonsall 2008, s. 245). Faza pierwsza została rozpoznana w jaskini Climetne II. Na inwentarz składały się między innymi różne odmiany drapaczy tarnowiańskich, ostrza romanelskie, ostrza graweckie, ostrza typu Climente I, fragmenty jednozadziorców, wiórki tylcowe, wiórki Dufour, rylce oraz łuszcznie. Odkryto również narzędzia wykonane z kości i poroża oraz fragmenty harpunów. W tej samej warstwie natrafiono na ludzki pochówek złożony w pozycji embrionalnej, ze śladami ochry na kościach (Boroneanţ V. 1999).

Fazy druga oraz trzecia reprezentowane są przez schronisko skalne Cuina Turcului oraz jaskinię Veterani (Boroneanţ V. 1999). W obu pochodzących z nich inwentarzach narzędzi stwierdzono przewagę technologii wiórowej. Odkryto tam różne formy drapaczy tarnowiańskich i innych, tylczaki pełnołukowe, mikrograwety, wiórki tylcowe, rylce, fragmenty jednozadziorców, wiórki Dufour. W porównaniu do jaskini Climente II nowe elementy były reprezentowane przez trapezy i trójkąty (Boroneanţ V. 1999).

Faza czwarta została zidentyfikowana na wyspie Ostrovul Banului, należącej do miejscowości Gura Văii. W trzech poziomach osadniczych odkryto liczne drapacze, które przeważały w inwentarzu narzędzi, ponadto ostrza clisuriańskie, mikroostrza, ostrza graweckie, trójkąty, tylczaki pełnołukowe, fragmenty jednozadziorców, wiórki Dufour, oraz staranie retuszowane odłupki i wióry. Dla kolejnych faz clisurienu stwirdzono rosnący udział wy-

\footnotetext{
${ }^{3}$ Nazwa została zaczerpnięta od Clisury - tak określanej rumuńskiej część Żelaznej Bramy; w Serbii używa się nazwy Djerdap.
} 
robów mikrolitycznych, przy jednoczesnym zachowaniu szeregu charakterystycznych poprzednich form narzędzi. Na serbskim brzegu Dunaju podobne znaleziska pochodzą ze stanowisk Padina i Vlasac (Boroneanţ V. 1999).

Niektóre elementy kultury materialnej schyłkowoplejstoceńskich łowców-zbieraczy stwierdzono również dla początków holocenu w Żelaznej Bramie; jest to pierwsza faza rozwojowa tzw. kultury Schela Cladovei-Lepenski Vir. Głównymi elementami łączącymi zaliczone do niej stanowiska są obrządek pogrzebowy, budownictwo i gospodarka (Boroneanţ A. 2012, s. 42). Zmiana w stosunku do clisurienu to przede wszystkim wzrost znaczenia technologii odłupkowej. Za najstarsze stanowisko uznawana jest Veterani - terasa. W odkrytym tam inwentarzu znalazły się między in ostrza clisuriańskie, różne odmiany drapaczy tarnowiańskich, przekłuwacze i rylce; część narzędzi (drapacz, przekłuwacz i rylce) wykonano z kwarcytu. Udział wyrobów z kwarcytu jest większy na kolejnych stanowiskach - w Icoanie znacznie przeważają one nad tymi wykonanymi z krzemienia. Na stanowisku tym występują też ostrza clisuriańskie oraz drapacze tarnowiańskie i inne. Również na stanowisku w Schela Cladovei podstawowym surowcem, z którego wykonano narzędzia jest kwarcyt, natomiast mniejszy udział stanowią wyroby z różnych odmian krzemienia bałkańskiego. Clive Bonsall interpretuje to stanowisko jako osadę rybaków. Z osadnictwem epipaleolitycznym w Schela Cladovei związany był bardzo ubogi inwentarz narzędzi, na który składały się głównie drapacze i skrobacze, a także przekłuwacze i ostrza clisuriańskie. Znacznie większy udział stanowiły narzędzia wykonane z kości i poroża (Bonsall 2008, s. 255-264). Inne stanowiska zaliczone do pierwszej fazy tzw. kultury Schela Cladovei-Lepenski Vir to: Alibeg, Padina, Vlasac, Răzvrata, ponadto przyporządkowano do niej bogaty inwentarz z poziomów IIIa i IIIb na stanowisku Ostrovul Banului. Aurelian Rusu, podsumowując wieloletnie badania nad opisywanymi zjawiskami, przedstawił zmienioną chronologię popartą nowymi datami radiowęglowymi. Według tego badacza kultura Schela Cladovei-Lepenski Vir funkcjonowała w latach 9500-6000 cal. BC; w tych ramach wyznaczył on trzy fazy jej funkcjonowania. Dla pierwszej charakterystyczne było przeżywanie się poprzednich, schyłkowoglacjalnych form kultury materialnej. Choć data $9500 \mathrm{cal} \mathrm{BC}$ zbiega się ustalonymi przez A. Walandusa i D. Nalepkę (2010) granicami chronozon, należy brać pod uwagę, że charakterystyczne dla Preborealu zmiany klimatu w Żelaznej Bramie mogły pojawić się nawet 200 lat wcześniej (Boroneant V. 1999; Cârciumaru i in. 2007). 


\section{ŚRODOWISKO PRZYRODNICZE U SCHYEKU PLEJSTOCENU I NA PO- CZĄTKU HOLOCENU W ŻELAZNEJ BRAMIE}

Jak wcześniej wspomniano, region Żelaznej Bramy tworzą trzy zróżnicowane morfologicznie strefy: Wąwóz Żelaznej Bramy, Karpaty wraz z górami Wschodnioserbskimi oraz dolina Dunaju. Współcześnie, obszar ten charakteryzuje się dostrzegalną różnicą względem umiarkowanego klimatu kontynentalnego typowego dla Rumunii i Serbii. Średnie roczne temperatury są o $0,5-0,8^{\circ} \mathrm{C}$ niższe niż na sąsiednich terenach. Temperatury zarejestrowane w lipcu są niższe o $2-3^{\circ} \mathrm{C}$, natomiast w styczniu wyższe o $0,1-1,2^{\circ} \mathrm{C}$ w stosunku do sąsiadujących obszarów. W regionie Żelaznej Bramy występuje również $20 \%$ więcej opadów niż na pozostałych obszarach Rumunii (Boroneanţ A. 2011).

W Żelaznej Bramie wyróżniono cztery rodzaje mikroklimatów:

- wyspiarski (np. Ostrovul Banului, Ostrovul Corbului, Ostrovul Mare);

- niższych teras Dunaju, charakteryzujący się występowaniem roślinności trawiastej (np. Icoana, Răzvrata, Schela Cladovei, Veterani Terasă, Cuina Turcului);

- środkowych teras (II-IV) Dunaju, nieznacznie chłodniejszy w porównaniu do niższych teras (temperatury są niższe o $1-2^{\circ} \mathrm{C}$ ) oraz z mniejszą liczbą słonecznych dni na zachodnich i północnych stokach doliny

- wyższych teras (V-VII) Dunaju opisywany jako wietrzny i mglisty, z postępującą redukcją słonecznych dni w roku (Boroneanţ A. 2011).

Jak łatwo zauważyć, późnoglacjalne i wczesnoholoceńskie osadnictwo skupiało się na wyspach rzecznych i na niższych terasach Dunaju, z niemal całkowitym pominięciem wyższych partii doliny. Niewykluczone, że wyższe partie doliny zasiedlane były w okresie funkcjonowania trzeciej fazy tzw. kultury Schela Cladovei-Lepenski Vir, czyli pomiędzy 6000 a 6300 cal BC. Miałoby to związek z chłodną oscylacją klimatyczną holocenu sprzed 8200 lat, powszechnie określaną jako „8.2 ka cold event” (Bonsall 2007). Natomiast podczas plejstocenu położenie topograficzne regionu Żelaznej Bramy powodowało, że wszelkie kontynentalne oscylacje klimatyczne były tutaj łagodniejsze i mniej odczuwalne (Boroneanţ 2011).

Badania palinologiczne przeprowadzone w schronisku skalnym Cuina Turcului, nawiązującej do clisurienu, wskazują na obecność w tym okresie w Żelaznej Bramie świerków, jodły i olchy, ze stałym wzrostem proporcji dębu i lipy, a także z dostrzegalnym spadkiem ilości pyłku sosny (Bolomey 
1973). Oznacza to, że zbiorowiska roślinne typowe dla preborealu pojawiły się na opisywanym obszarze przynajmniej 2000 lat wcześniej niż w północnej i zachodniej Europie (Boroneanţ 1999). Warto również zauważyć, że rozprzestrzeniające się z południowego wschodu dąb i lipa, zasiedliły Niż Środkowoeuropejski dopiero w okresie borealnym (Latałowa 2003a; 2003b). $\mathrm{Na}$ faunę stanowiska Cuina Turcului składały się głównie szczątki dzika, bobra zwyczajnego i koziorożca, a także - w nieco mniejszej ilości - tura, łosia, wilka, niedźwiedzia brunatnego i jelenia szlachetnego (Bolomey 1973). Okres ten nazywany jest przez rumuńskich badaczy Erbiceni A i prawdopodobnie zbiegł się z oscylacją bølling w północnej i zachodniej Europie. Następne okresy, które obserwujemy to tzw. faza brzozowa i ponownie faza sosnowa, chronologicznie odpowiadające starszemu dryasowi. Po nich następuje okres zwany Erbiceni B, analogiczny do allerødu i charakteryzujący się występowaniem lasów sosnowych z dużą ilością świerków. Faza sosnowa kończy się w Rumunii wraz z końcem plejstocenu. Początek holocenu w Żelaznej Bramie cechowała przewaga świerku nad sosną oraz rosnące znaczenie dębu i olchy (Ciârciumaru i in. 2007).

\section{ZBIEŻNOŚCI INWENTARZY KRZEMIENNYCH W ZESPOLACH EPIPALEOLITYCZNYCH I MEZOLITYCZNYCH}

Zespoły epipaleolityczne w Żelaznej Bramie chrakteryzują się znaczną zbieżnością cech technologiczno-typologicznych. Głównym półsurowcem służącym do wytwarzania narzędzi w protoclisurienie i clisurienie były wióry. Dopiero dla pierwszej fazy tzw. kultury Schela Cladovei-Lepenski Vir odnotowano wzrost znaczenia technologii odłupkowej (było to zapewne spowodowane wykorzystywaniem innych, gorszych jakościowo surowców), jednak nadal w inwentarzu krzemiennym stanowiska Ostrovul Banului występują wiórowe zatępce. Narzędziami typowymi dla epipaleolitu są: mikrolityczne zbrojniki geometryczne, różne odmiany drapaczy tarnowiańskich, skrobacze wielorakie, rylce, zgrzebła, a także ostrza azylskie oraz duże i małe formy tylcowe. Dla pełniejszego zinterpretowania i porównania inwentarzy krzemiennych w Żelaznej Bramie niezbędne jest przeanalizowanie szerszego spektrum zespołów epipaleolitycznych występujących w strefie wschodnioalpejsko-karpacko-bałkańskiej. Dopiero nadanie zespołom kulturowym w południowej Europie charakteru kompleksów technologicznych umożliwiłoby wyczerpujące zestawienie ich ze schyłkowopaleolitycznymi i mezolitycznymi inwentarzami narzędziowymi. Jednak tak szeroka analiza typologiczno- 
-technologiczno-porównawcza wykracza poza ramy tego artykułu, którego celem jest, między innymi, przedstawienie adaptacjonistycznej interpretacji zjawisk kulturowych u schyłku późnego glacjału i w początkach holocenu w Żelaznej Bramie.

Inwentarze krzemienne zespołów mezolitycznych również wykazują znaczne zbieżności cech technologiczno-typologicznych. Holoceńskie społeczności łowiecko-zbierackie na Niżu Środkowoeuropejskim wykorzystywały wszystkie znane wcześniej typy i formy rdzeni. Podstawowymi narzędziami w zespołach mezolitycznych są przede wszystkim zbrojniki, ponadto: drapacze, rylce, skrobacze wielorakie, półtylczaki, pazury, wiórowce, ciosaki, piki. Mniej licznie występują: zgrzebła, raklety, wiertniki, narzędzia zębate i narzędzia wnękowe (Galiński 2002). Obfitość z jaką zbrojniki występowały na stanowiskach mezolitycznych przyczyniły się do stworzenia, na podstawie ich różnorodności, wewnętrznej systematyki taksonomicznej mezolitu. Formy narzędzi występujące w zespołach preborealnych i wczesnoborealnych, czyli między innymi tylczaki łukowe i pełnołukowe oraz trójkąty nierównoboczne rozwartokątne o małym boku długim występują już w inwentarzach $\mathrm{z}$ clisurienu na stanowisku Cuina Turcului oraz w młodszych inwentarzach w Żelaznej Bramie. Zgodnie z analizą Tadeusz Galińskiego (2002), pojawiające się od końca pierwszej połowy okresu borealnego w zespołach mezolitycznych różne odmiany małych, wąskich trójkątów nierównobocznych, a także różne kategorie tzw. prostokątów i wiórków tylcowych, znane są z wcześniej datowanych niemezolitycznych stanowisk w strefie śródziemnomorsko-bałkańsko-nadczarnomorskiej. Podobnie zbrojniki trapezowate, które pojawiają się w zespołach mezolitycznych z początku okresu atlantyckiego, znane są $\mathrm{z}$ późnoglacjalnych stanowisk w dolinie Dunaju. Zatem zarówno wewnątrz zespołów mezolitycznych i epipaleolitycznych oraz bezpośrednio pomiędzy omawianymi zespołami występują znaczne zbieżności technologiczno-typologiczne. Natomiast struktura wewnętrzna poszczególnych inwentarzy, czyli wartości ilościowe oraz różne formy zbrojników zależą od wielu czynników zewnętrznych, z których ważną (prawdopodobnie decydującą) rolę odgrywało środowisko (Galiński 2002).

\section{MEZOLIT CZY EPIPALEOLIT?}

Problem klasyfikacji powyższych zespołów kulturowych jest częścią szerszej dyskusji dotyczącej mezolitu i epipaleolitu w Żelaznej Bramie. Badacze spierają się, czy oba te pojęcia są jednoznaczne, czy opisują zupełnie inne 
systemy społeczno-gospodarcze, a w związku z tym, którego z nich powinniśmy używać w odniesieniu do południowej części kontynentu europejskiego?

Vasile Boroneanţ nazywa te zjawiska epipaleolitem, który według niego jest odpowiednikiem mezolitu. Proces rozwoju tego rodzaju ugrupowań miał rozpocząć się nad Dunajem, a następnie wzdłuż rzeki Sawy i jej dopływu Driny, poprzez Adriatyk, którego poziom wód był wówczas dużo niższy niż obecnie, dotarł do Półwyspu Apenińskiego. Inna gałąź migracji miałaby przebiegać również wzdłuż Sawy na obszar dzisiejszej Słowenii (Boroneanţ V. 1999), bowiem zauważalne są pewne zbieżności ze słoweńskim mezolitem (Turk 2004), jak również z szeregiem innych obszarów o epigraweckim podłożu.

Alexandru Păunescu uważa natomiast, że epipaleolit i mezolit w Żelaznej Bramie to dwa różne zjawiska, z których pierwszy okres trwał od początku böllingu do końca lub połowy preborealu. $Z$ epipaleolitem wiąże on szereg stanowisk w miejscowości Dubova: jaskinię Climetne I i II, jaskinię Veterani, Veterani - terasa, schronisko skalne Cuina Turcului, a także Icoana i Răzvrata. Następnie od połowy preborealu do końca borealu trwał mezolit identyfikowany z kulturą Schela Cladovei, nazywaną również kulturą Schela Cladovei-Lepenski Vir. Oprócz tych dwóch stanowisk, A. Păunescu zalicza do mezolitu również: Ogradena, Icoana, Poiana Roman oraz Cornul Malului (Păunescu 2001, s. 67).

Z kolei badacz Lepenskiego Viru - Dragostan Srejović w swoich pierwszych pracach podawał, że Lepenski Vir we wczesnej fazie, czyli proto-Lepenski Vir, prezentował osadnictwo epipaleolityczne, w późniejszych zaś protoneolityczne; wyraził tym samym przekonanie o rodzimym pochodzeniu rolnictwa i wytwórstwa ceramiki w tym regionie (Bonsall 2008, s. 239-240).

Według C. Bonsall'a mimo, że w innych rejonach Europy zmiany w inwentarzach narzędzi połączone $\mathrm{z}$ istotnymi zmianami klimatycznymi wyznaczały pojawienie się ugrupowań mezolitycznych, to na obszarze Żelaznej Bramy nie odgrywały one żadnej lub bardzo niewielką rolę. Badacz proponuje więc bardzo wczesną chronologię mezolitu, który miałby rozpocząć się 13000 cal BC (Bonsall 2008, s. 239-240).

Pośród definicji opisujących mezolit i jego genezę (np. Więckowska 1975; Kozłowski J. K., Kozłowski S. K. 1977; Mussi 2001; Galiński 2002; Kozłowski J. K. 2004) należy szukać tych, które uwzględniają największą liczbę zmiennych. Tymi zmiennymi są wszelkie atrybuty definiujące poszczególne ugrupowania, przede wszystkim społeczno-gospodarcze, technologiczne i środowiskowe. Definicje mezolitu oparte jedynie na kryteriach ekologiczno-gospodarczych są niewystarczające i niejasne przy szerszym rozpatrywaniu 

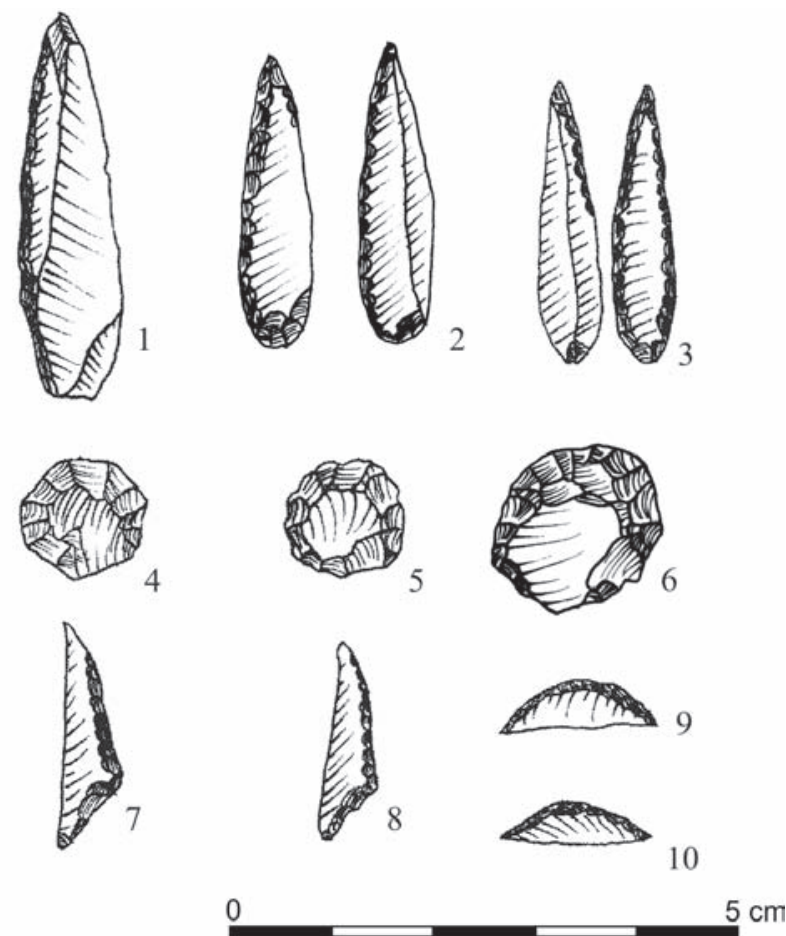

Ryc. 2. Wybrane narzędzia epipaleolityczne (protolisurien i clisurien): 1 - ostrze typu La Gravette; 2-3 - ostrza typu Climente I; 4-6 - okółkowe drapacze tarnowiańskie; 7-8 - trójkąty nierównoboczne rozwartokątne; 9-10 - mikrolityczne tylczaki pełnołukowe. 1 - Climente II (clisurien); 2-3 - Climente I (protoclisurien); 4-10 - Cuina Turcului (clisurien) (wg Boroneanţ V. 2000)

Fig. 2. Selected epipaleolithic tools (protoclisurien and clisurien): 1 - La Gravette point; 2-3 - Climente I point; 4-6 - Tarnovian end-scrapers; 7-8 - scalene and obtuse triangles; 9-10 - crescent-shaped backed bladelets. 1 - Climente II (clisurien); 2-3 - Climente I (protoclisurien); 4-10 - Cuina Turcului (clisurien) (after Boroneanţ V. 2000)

zjawisk kulturowych (Galiński 2002). Przykład definicji czysto ekonomicznej odnajdujemy w publikacjach badaczy włoskich (Mussi 2002, s. 286-288). Według nich na skutek zmian klimatycznych i wynikającej z nich potrzeby zmodyfikowania narzędzi przystosowanych do polowania na małe ssaki, ryby, ptaki i inne, wszelka akumulacja szczątków małej fauny, nawet gdy dotyczyła późnego glacjału, powinna być nazywana mezolitem. Taka definicja jest nie do przyjęcia, gdyż geneza mezolitu jest skomplikowanym procesem przekształceń kulturowych na obszarze alpejsko-skandynawskiej Europy i związana jest z gwałtownym ociepleniem klimatu pod koniec okresu późnoglacjalnego i w początkach holocenu. Według adaptacjonistów mezolit europejski to jeden technokompleks kulturowy, ściśle związany ze środowiskiem młodych, 
Tabela. 1. Proponowana chronologia zespołów kulturowych w Żelaznej Bramie

\begin{tabular}{|c|c|c|c|}
\hline \multicolumn{2}{|c|}{ Zespoły kulturowe } & Chronologia & Stanowiska \\
\hline & protoclisurien & $\begin{array}{c}\text { około } \\
13000 / 12000 \text { cal BC }\end{array}$ & Peştera Climente I \\
\cline { 2 - 4 } & clisurien & $12000-9500 \mathrm{cal} \mathrm{BC}$ & $\begin{array}{c}\text { Peştera Climente II, Cuina Turcului, } \\
\text { Peştera Veterani, Ostrovul Banului, } \\
\text { Peştera Hoţilor, Padina, Vlasac }\end{array}$ \\
\hline \multirow{2}{|c|}{} & $\begin{array}{c}\text { I faza tzw. kultury } \\
\text { Schela Cladovei- } \\
\text { Lepenski Vir }\end{array}$ & $9500-7200$ cal BC & $\begin{array}{c}\text { Schela Cladovei, Lepenski } \\
\text { Vir, Ostrovul Banului, Icoana, } \\
\text { Alibeg, Răzvrata, Ostrovul Mare, } \\
\text { Veterani - terasa, Ostrovul Corbului, } \\
\text { Padina, Vlasac }\end{array}$ \\
\hline
\end{tabular}
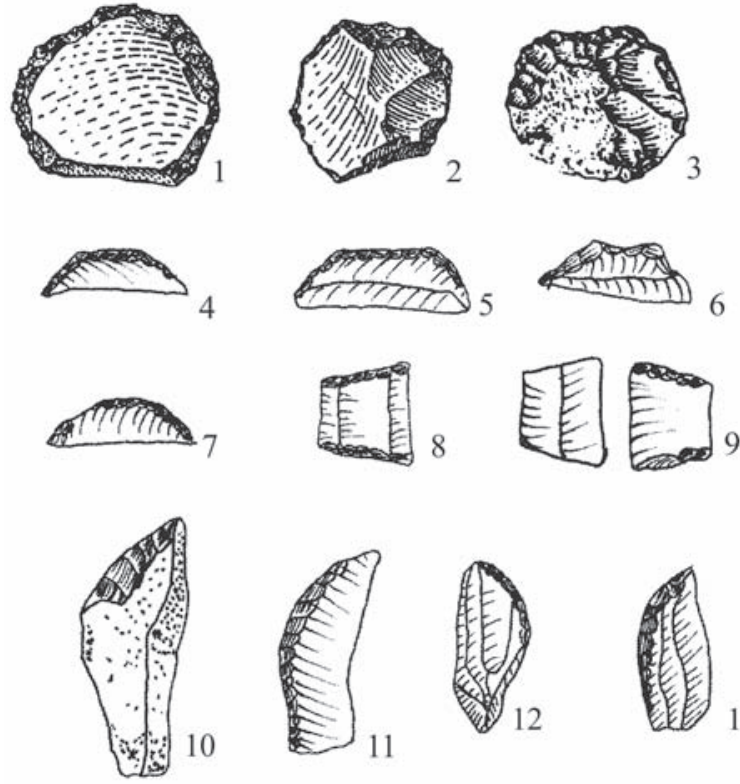

0

$5 \mathrm{~cm}$

Ryc. 3. Wybrane narzędzia epipaleolityczne (clisurien i tzw. kultura Schela Cladovei-Lepenski Vir): 1-3 - okółkowe drapacze tarnowiańskie; 4-6 - zbrojniki trapezowate; 7 - mikrolityczny tylczak pełnołukowy; 8-9 - trapezy; 10-13 - ostrza typu clisurien. 1-2 - Icoana (Schela Cladovei-Lepenski Vir); 3-7 - Cuina Turcului (clisurien); 8-9, 13 - Padina (Schela Cladovei-Lepenski Vir); 10-12 - Schela Cladovei (Schela Cladovei-Lepenski Vir) (wg Boroneanţ V. 2000)

Fig. 3. Selected epipaleolithic tools (clisurien and so-called Schela Cladovei-Lepenski Vir culture): 1-3-Tarnovian end-scrapers; 4-6-trapeze-shaped backed bladelets with truncation; 7 - crescent-shaped backed bladelet; 8-9 - trapezes; 10-13 - clisurean points. 1-2 - Icoana (Schela Cladovei-Lepenski Vir); 3-7 - Cuina Turcului (clisurien); 8-9, 13 - Padina (Schela Cladovei-Lepenski Vir); 10-12 - Schela Cladovei (Schela Cladovei-Lepenski Vir) (after Boroneanţ V. 2000) 
zwartych lasów strefy umiarkowanej Europy Zachodniej. Charakteryzuje się ściśle określonymi właściwościami technologicznymi odróżniającymi je od innych, współczesnych im ugrupowań kulturowych Europy (Galiński 2002). Adaptacja, jako proces stawania się, doprowadziła do powstania ugrupowań mezolitycznych, do których nie zaliczamy: wczesnocholoceńskich ugrupowań liściakowych Skandynawii (określanych jako kultury: Fosna, Komsa, Askola, Suomusjarvi, Hensbacka), wczesnoholoceńskich ugrupowań liściakowych występujących na Niżu Rosyjskim i w strefie wschodniobałtyckiej (w tym kompleksu kundajskiego), wczesnoholoceńskich ugrupowań strefy nadczarnomorskiej (w tym tzw. kręgu krymsko-kaukaskiego), wczesnoholoceńskich ugrupowań strefy nadczarnomorsko-śródziemnomorskiej, od dawna określanych jako epigraweckie albo epitardigraweckie. Wymienione wyżej ugrupowania nie mieszczą się w ramach mezolitu i powinny być określane jako epipaleolit (Galiński 2002, s. 15). Ten sam termin należy stosować w kontekście późnoglacjalnych i wczesnoholoceńskich zespołów kulturowych w Żelaznej Bramie, które kontynuują tradycje leśnego modelu adaptacyjnego kultury górnopaleolitycznej. Pomimo niewielkich różnic na wszystkich opisanych wyżej stanowiskach odkryto formy narzędzi znanych później w ugrupowaniach mezolitycznych na Niżu Środkowoeuropejskim; są to: technika wiórkowa, technika rylcowcza, technika retuszu surowego boku w zbrojnikach, duże i małe formy tylcowe, mikrolityczne zbrojniki geometryczne, różnorodne odmiany drapaczy tarnowiańskich, skrobacze wielorakie, rylce, zgrzebła (Galiński 2002), a także szereg innych form identyfikowanych z epigrawetienem śródziemnomorskim. Stanowi to dowód na udział zespołów kulturowych z południowej Europy w kształtowaniu się mezolitycznego systemu kulturowego w strefie alpejsko-skandynawskiej. Natomiast nie ma uzasadnienia, aby zespoły te nazywać mezolitycznymi, jednocześnie przesuwając granicę jego genezy o kilka tysięcy lat wstecz. Tak intensywnych zmian środowiska przyrodniczego i procesów przekształceń kulturowych związanych z rozpadem ugrupowań późnopaleolitycznych na Niżu Środkowoeuropejskim nie odnotowano w strefie karpacko-bałkańskiej dla początku holocenu, co zapewne było przyczyną powstania zróżnicowań kulturowych w pozornie takim samym środowisku leśnym (Krawczak 2003). Holoceńskie zespoły kulturowe na obszarze Żelaznej Bramy w początkowej fazie istnienia nadal charakteryzował epipaleolityczny model adaptacji do środowiska. Następnie w Żelaznej Bramie pojawiały się zespoły protoneolityczne, które około 6000 cal BC osiągnęły neolityczny model kultury (Boroneanţ A. 2012).

Pojęcie epipaleolit nie jest jednoznaczne z mezolitem. Nie ma uzasadnienia, aby nazwę tę stosować zamiennie jako odpowiednik mezolitu w krajach 
śródziemnomorskich i strefie karpacko-bałkańskiej (Kozłowski J. K. 2004, s. 128). Jeśli na pewnym obszarze nie ma uzasadnienia stosowania nazwy mezolit, nie należy szukać jej zamiennika.

\section{PODSUMOWANIE}

Prowadzone od lat 20. XX wieku badania nad osadnictwem pradziejowym w Rumunii zaowocowały odkryciem licznych przykładów osadnictwa epipaleolitycznego. Nagromadzenie tego rodzaju stanowisk w regione Żelaznej Bramy jest skutkiem podejmowanych w latach 60. i 70. XX wieku archeologicznych badań ratowniczych, poprzedzających budowę dwóch tam rzecznych na Dunaju. Śladami osadnictwa ze schyłku późnego glacjału i początków holocenu w Żelaznej Bramie są ugrupowania kontynuujące tradycję leśnego modelu adaptacyjnego kultury górnopaleolitycznej.

Proces adaptacji opisywanych ugrupowań skutkował poszerzaniem się inwentarza narzędziowego o wyroby i techniki znane później w kręgu ugrupowań mezolitycznych w strefie alpejsko-skandynawskiej. Na południu Europy, na pograniczy plejstocenu i holocenu, nie zaistniały zjawiska klimatyczne, z jakimi związana była geneza mezolitu w zachodniej Europie. Zatem zespoły kulturowe w Żelaznej Bramie należy określać mianem epipaleolitu, który jest wyrazistym, chociaż niejednorodnym modelem adaptacji kulturowej funkcjonującym na obrzeżach zjawisk późnopaleolitycznych i mezolitycznych (m.in. południowych i południowo-wschodnich).

\section{LITERATURA}

Berciu D.

1939 Arheologia preistorică a Olteniei, Craiova.

Bolomey A.

1973 The present stage of knowledge of mammal exploitation during the Epipalaeolithic and the earliest Neolithic on the territory of Romania, [w:] Domestikationsforschung und geschichte der haustiere, red. J. Matolcsi, Budapest, s. 197-203.

Bonsall C.

2007 When was the Neolithic transition in the Iron Gates?, [w:] A short walk through the Balkans: the first farmers of the Carpathian Basin and Aajacent regions, red. M. Spataro, P. Biagi, Società Preistoria Protostoria Friuli - V.G., Quaderno 12, Trieste, s. 53-66. 
2008 The Mesolithic of the Iron Gates, [w:] Mesolithic Europe, red. G. Bailey, P. Spikins, Cambridge, s. 238-203.

Borić D., French Ch., Dimitrijević V.

2008 Vlasac revisited: formation processes, stratigraphy and dating, Documenta Praehistorica, t. 35, s. 261-279.

Boroneanţ A.

2011 A suggestet chronology for the Iron Gates Mesolithic, Buletinul Muzeului Judeţean Teleorman, Seria Arheologie 3, s. 21-39.

2012 Aspecte ale tranziţiei de la mezolitic la neoliticul timpuriu în zona Porţile de Fier, Cluj-Napoca.

Boroneanţ A., Dinu A.

2006 The Romanian Mesolithic and the transition to farming. A case study: the Iron Gates, Studii de Preistorie, t. 3, s. 41-76.

Boroneanţ V.

1999 The Mesolithic Habitation Complexes in the Balkans and the Danube Basin, Living Past 1, URL: http://www.cimec.ro/livingpast/nr1/boroneant/mesolithic.htm.

2000 Paleolithique superieur et epipaleolithique dans la zone des Portes de Fer, Bucureşti.

Cârciumaru M., Anghelinu M., Niţu E.C., Cosac M., Murătoreanu G.

2007 Geo-Archéologie du Paléolithique moyen, Paléolithique supérieur, Epipaléolithique et Mésolithique en Roumanie, Târgovişte.

Dinu A., Soficaru A., Miritoiu D.

2007 The Mesolithic at the Danube's Iron Gates: new radiocarbon dates and old stratigraphies, Documenta Praehistorica, t. 34, s. 31-52.

Galiński T.

2002 Spoleczeństwa mezolityczne. Osadnictwo, gospodarka, kultura ludów łowieckich w VIII-IV tys. p.n.e. na terenie Europy, Szczecin.

Ginter B., Kozłowski J.K.

1990 Technika obróbki i typologia wyrobów kamiennych paleolitu, mezolitu i neolitu, Warszawa.

Kobusiewicz M.

2009 Czy istniała kultura Bromme? Folia Praehistorica Posnaniensia, t. 15, s. $75-91$.

Kozłowski J. K.

1973 The Probleme of the so-called Danubian Mesolithic, [w:] The Mesolithic in Europe, red. S. K. Kozłowski, Warszawa, s. 315-330.

2004 Wielka historia świata, t. 1: Świat przed „rewolucją neolityczna, Kraków.

Kozłowski J. K., Kozłowski S. K.

1977 Epoka kamienia na ziemiach polskich, Warszawa. 
Kozłowski S. K.

1981 Mezolit, [w:] Kultury i ludy dawnej Europy, Warszawa, s. 59-68.

Krajcarz M.

2009 Redepozycja szczątków kostnych na stanowiskach jaskiniowych. Znaczenie dla badań biostratygraficznych, [w:] Strefa marginalna lądolodu zlodowacenia Warty i pojezierza plejstoceńskie na południowym Podlasiu. XVI Konferencja Stratygrafia plejstocenu Polski, Zimna Woda k. Łukowa, 31.08.-04.09.2009 r., red. M. Żarski, S. Lisicki, Warszawa, s. $114-116$.

Krawczak E.

2003 Antropologia kulturowa. Klasyczne kierunki, szkoły, orientacje, Lublin. Latałowa M.

2003 Holocen, [w:] Palinologia, red. S. Dybova-Jachowicz, A. Sadowska, Kraków, s. 273-307.

2003 Późny vistulian, [w:] Palinologia, red. S. Dybova-Jachowicz, A. Sadowska, Kraków, s. 266-273.

Mussi M.

2002 Earliest Italy. An Overview of the Italian Paleolithic and Mesolithic, New York, Boston, Dordrecht, London, Moscow.

Nicolăescu-Plopşor C. S.

1931 Les cultures mesolithiques en Oltenie, [w:] XV Congrès Internationale d'Anthropologie \& d'Archéologie Préhistorique, Paris, s. 406-409.

Păunescu A.

2000 Paleoliticul şi mezoliticul din spaţiul cuprins între Carpaţi şi Dunăre. Studiu monografic, Bucureşti.

2001 Paleoliticul şi mezoliticul din spaţiul transilvan. Studiu monografic, Bucureşti.

Rusu A.

2011 Lepenski Vir-Schela Cladovei Culture’s Chronology and its Interpretation, Brukenthal. Acta Musei, VI. 1.

Schild R.

1975 Późny paleolit, [w:] Paleolit i mezolit, red. W. Chmielewski, R. Schild, H. Więckowska, Warszawa, s. 159-338.

Srejović D.

1969 The roots of the Lepenski Vir culture, Archaeologia Jugoslavica 10, s. $13-21$.

Turk I.

2004 Viktorjev spodmol in/and Mala Triglavca. Contributions to understanding the Mesolithic period in Slovenia, Opera Instituti Archaeologici Sloveniae 9, s. 9-274. 
Walanus A., Nalepka D.

2010 Calibration of Mangerud's Boundaries, Radiocarbon, t. 52, $\mathrm{nr} 4$, s. $1639-1644$.

Więckowska H.

1975 Społeczności łowiecko-rybackie wczesnego holocenu, [w:] Paleolit i mezolit, red. W. Chmielewski, R. Schild, H. Więckowska, Warszawa, s. 339-438.

Voytek, B., Tringham R.

1989 Rethinking the Mesolithic: The case of south-east Europe, [w:] The Mesolithic in Europe. Proceedings of the 3rd International symposium, red. C. Bonsall, Edinburgh, s. 492-499.

\section{CULTURAL GROUPS IN IRON GATES REGION DURING THE DE- CAY OF LATE GLACIAL AND THE BEGINNING OF HOLOCEN}

\section{Summary}

The Iron Gates region can be defined as 134 kilometers long section of the Danube valley (230 km with lowland zone). It contains three, distinct, physiographic zones: Iron Gates gorge, Carpathian and Balkan mountain chain and a lowland zone of the Danube valley (with more moderate relief). First systematic excavations in Iron Gates started in 1964 as a response to an agreement between the Socialist Republic of Romania and the Socialist Federative Republic of Yugoslavia to build a hydroelectric power station at Gura Văii. During the research archaeologists found many Epipaleolithic, Protoneolithic and Neolithic sites, including most known Cuina Turcului rock shelter, Schela Cladovei and Lepenski Vir. The main issue of this article is to revise the cultural groups in Iron Gates during the decay of Late Glacial and the beginning of Holocen. These groups are often defined as Mesolithic groups, which is incompatible with the most comprehensive approach to European Mesolithic.

Translated by Pawet Wójcicki

Adres do korespondencji:

Pawet Wójcicki

Instytut Archeologii i Etnologii PAN

Al. Solidarności 104, 00-140 Warszawa

pawel_wojcicki@op.pl 
